\title{
Adding liquid feed to a total mixed ration reduces feed sorting behavior and improves productivity of lactating dairy cows
}

\author{
T. J. DeVries ${ }^{\star 1}$ and R. M. Gill† \\ *Department of Animal and Poultry Science, University of Guelph, Kemptville Campus, 830 Prescott Street, Kemptville, ON K0G 1J0, Canada \\ †Liquid Feeds International Ltd., Box \#399, Innerkip, ON N0J 1M0, Canada
}

\begin{abstract}
This study was designed to determine the effect of adding a molasses-based liquid feed (LF) supplement to a total mixed ration (TMR) on the feed sorting behavior and production of dairy cows. Twelve lactating Holstein cows $(88.2 \pm 19.5$ DIM) were exposed, in a crossover design with 21-d periods, to each of 2 treatment diets: 1) control TMR and 2) control TMR with $4.1 \%$ dietary dry matter LF added. Dry matter intake (DMI), sorting, and milk yield were recorded for the last $7 \mathrm{~d}$ of each treatment period. Milk samples were collected for composition analysis for the last 3 $\mathrm{d}$ of each treatment period; these data were used to calculate $4 \%$ fat-corrected milk and energy-corrected milk yield. Sorting was determined by subjecting fresh feed and orts samples to particle separation and expressing the actual intake of each particle fraction as a percentage of the predicted intake of that fraction. Addition of LF did not noticeably change the nutrient composition of the ration, with the exception of an expected increase in dietary sugar concentration (from 4.0 to $5.4 \%$ ). Liquid feed supplementation affected the particle size distribution of the ration, resulting in a lesser amount of short and a greater amount of fine particles. Cows sorted against the longest ration particles on both treatment diets; the extent of this sorting was greater on the control diet (55.0 vs. $68.8 \%$ ). Dry matter intake was $1.4 \mathrm{~kg} / \mathrm{d}$ higher when cows were fed the LF diet as compared with the control diet, resulting in higher acid-detergent fiber, neutral-detergent fiber, and sugar intakes. As a result of the increased DMI, cows tended to produce $1.9 \mathrm{~kg} / \mathrm{d}$ more milk and produced 3.1 and $3.2 \mathrm{~kg} / \mathrm{d}$ more $4 \%$ fat-corrected milk and energy-corrected milk, respectively, on the LF diet. As a result, cows tended to produce more milk fat $(0.13$ $\mathrm{kg} / \mathrm{d})$ and produced more milk protein $(0.09 \mathrm{~kg} / \mathrm{d})$ on the LF diet. No difference between treatments was observed in the efficiency of milk production. Overall,
\end{abstract}

Received September 21, 2011.

Accepted January 3, 2012.

${ }^{1}$ Corresponding author: tdevries@uoguelph.ca adding a molasses-based LF to TMR can be used to decrease feed sorting, enhance DMI, and improve milk yield.

Key words: liquid feed, molasses, sorting, dairy cow

\section{INTRODUCTION}

Total mixed rations are designed to be a homogenous mixture that provides dairy cattle a balanced supply of nutrients within a day and across multiple days within a given stage of lactation. Unfortunately, cows fed TMR will often preferentially select (sort) for the grain component and discriminate against the longer forage components (Leonardi and Armentano, 2003). Excessive sorting of TMR can result in over-consumption of rapidly fermentable carbohydrates, increasing the risk of SARA (DeVries et al., 2008).

Adding water to dry TMR has traditionally been considered beneficial to decrease feed sorting (Shaver, 2002), as it should help promote ration adhesiveness. Leonardi et al. (2005) reported that decreasing TMR DM concentration from 81 to $64 \%$, through water addition, decreased feed sorting. The applicability of these results can be questioned as the ration tested in that study was much drier than that typically used on high-producing dairy farms (40 to 60\% DM; Eastridge, 2006). Researchers have recently demonstrated that adding water to wetter TMR (less than $60 \%$ DM), containing only fermented forage sources, actually encouraged more sorting and limited DMI (Miller-Cushon and DeVries, 2009; Felton and DeVries, 2010).

It appears, therefore, that the addition of water to TMR may not always have the desired effect in terms of promoting ration adhesiveness and decreasing feed sorting. Potential exists for other products to promote ration adhesiveness. For example, molasses is well recognized for its ability to conglomerate small ration particles to larger particles. This may help decrease the selective consumption (sorting) against the long ration particles. This may be further promoted, given that molasses is sweet, and dairy cattle prefer sweettasting feeds (Nombekela et al., 1994). Such an increase in palatability may also help stimulate DMI (Firkins 
et al., 2008). In one previous study, the addition of a molasses-based liquid feed (LF) appeared to decrease the change in ration particle size in a corn silage-based diet, but not an alfalfa hay-based diet (Oelker et al., 2009). Unfortunately, Oelker et al. (2009) only looked at overall change in particle size (data not shown), and did not accurately quantify the amount of sorting (based on actual and predicted amounts of particles consumed). Eastridge et al. (2011) recently reported no effect of adding LF on sorting behavior; however, those researchers used a ration that was very dry $(>64 \%$ DM). Those researchers hypothesized that the high dietary DM may have limited the effectiveness of the LF on decreasing feed sorting. The objective of this study was to determine the effect of adding an LF supplement to a TMR, moderate in DM containing both corn silage and alfalfa haylage, on the feed sorting behavior and production of dairy cows. We hypothesized that adding an LF to a TMR will help bind ration components together and improve palatability, thus decreasing the selective consumption against long particles in the TMR while increasing overall DMI and milk yield.

\section{MATERIALS AND METHODS}

\section{Animals and Housing}

Twelve lactating Holstein dairy cows, including 6 primiparous and 6 multiparous (parity $=2.5 \pm 0.5$; mean \pm SD), were used in this study. The animals were 88.2 \pm 19.5 DIM at the beginning of the data collection. The cows were housed together in a tie-stall barn located at the University of Guelph, Kemptville Campus Dairy Education and Research Centre (Kemptville, ON, Canada). Cows were managed according to the guidelines set by the Canadian Council on Animal Care (CCAC, 2009). Each cow was individually housed in a tie-stall with ad libitum water (via individual water bowls) and feed (via a feed bunk containing removable dividers separating adjacent cows' feed). Cows were milked in their stalls twice daily at 0500 and $1600 \mathrm{~h}$. The cows were fed a TMR once daily at $1000 \mathrm{~h}$. Individual orts were removed and weighed before feed delivery. Cows were given a 2-h exercise period (0800 to $1000 \mathrm{~h}$ ) each day in an outdoor dry lot pen. The experiment was conducted from January 14 to February 24, 2011. The average environmental temperature during the collection periods was $-10.7 \pm 5.9^{\circ} \mathrm{C}$.

\section{Experimental Design and Diets}

The number of animals required per treatment was determined through power analysis (Morris, 1999) for the primary response variables, including DMI, feed sorting, and milk yield and composition. Estimates of variation for these variables were based on previously reported values (Leonardi et al., 2005; Bhandari et al., 2008; Felton and DeVries, 2010). Cows were divided into 2 groups of 6 , which were balanced according to DIM, milk yield, and parity, and then randomly assigned to 1 of the 2 treatments.

The cows were exposed, in a crossover design with 21-d periods, to each of 2 treatment diets (Tables 1 and 2): 1) control TMR and 2) control TMR with 4.1\% dietary DM LF (Dairy/Gold Rumen Enhancer; Liquid Feeds International Ltd., Innerkip, ON). The LF contained cane molasses, corn steep liquor, and corn distillers grains with solubles. The control diet was formulated to meet the nutrient requirements of lactating dairy cows at 90 DIM producing $40 \mathrm{~kg} / \mathrm{d}$ (NRC, 2001). Dietary ingredients were mixed for approximately 10 min in a TMR mixer wagon (Jaylor 4425; Jaylor Fabricating, Orton, ON, Canada). After mixing, the ration was transferred to a feed cart (WIC MDR-55; Ideal Machinery Inc., Wickham, QC, Canada) from which the cows were fed. For the LF diet, the LF was added into the feed cart, thoroughly mixed with the feed for $10 \mathrm{~min}$, and then delivered to the cows in that treatment. Prior to feed delivery, mixing times of both treatment rations within the automatic feeder and feed cart were similar. The amount of feed offered was adjusted daily to ensure approximately $10 \%$ orts (actual $=11.3$ $\pm 6.8 \%$; mean $\pm \mathrm{SD}$ ).

\section{Feed Sampling and Analysis}

Representative samples of the treatment TMR and individual orts of each cow were collected in duplicate daily for the last $7 \mathrm{~d}$ of each treatment period to determine DM and nutrient concentration, as well as for particle size separation. Additionally, on d 5, 12, and 19 of each treatment period, duplicate samples of the dietary components were collected for particle size and chemical analysis. All samples were immediately frozen at approximately $-20^{\circ} \mathrm{C}$ until they were further analyzed.

Samples for particle size separation were separated using a 3-screen (19-, 8-, and 1.18-mm) Penn State Particle Separator (PSPS; Kononoff et al., 2003). This device separated the particles into 4 fractions: long $(>19 \mathrm{~mm})$, medium $(<19$ and $>8 \mathrm{~mm})$, short $(<8$ and $>1.18 \mathrm{~mm})$, and fine $(<1.18 \mathrm{~mm})$ particles. After separation, the DM of each separated fraction was determined by oven drying at $55^{\circ} \mathrm{C}$ for $48 \mathrm{~h}$.

Samples collected for DM and chemical analysis were oven dried at $55^{\circ} \mathrm{C}$ for $48 \mathrm{~h}$ and then ground to pass through a 1-mm screen (Brinkmann Mill; Brinkmann Instruments Co., Westbury, NY). These samples, plus 
Table 1. Ingredient composition of the treatment diets

\begin{tabular}{lcc}
\hline $\begin{array}{l}\text { Ingredient, } \\
\text { \% DM }\end{array}$ & $\begin{array}{c}\text { Control } \\
\text { diet }\end{array}$ & $\begin{array}{c}\mathrm{LF}^{1} \\
\text { diet }\end{array}$ \\
\hline Corn silage $^{2}$ & 28.2 & 27.0 \\
Alfalfa haylage $^{3}$ & 27.8 & 26.7 \\
High-moisture corn $_{\text {Concentrate pellet }}{ }^{4}$ & 23.4 & 22.4 \\
Dairy/Gold $^{1}$ & 20.6 & 19.8 \\
\hline
\end{tabular}

${ }^{1} \mathrm{LF}=$ liquid feed; Dairy/Gold Rumen Enhancer (Liquid Feeds International Ltd., Innerkip, ON) had a DM content of $45.3 \pm 0.1 \%$ and chemical composition (DM basis) of $33.1 \pm 1.8 \% \mathrm{CP}, 2.8 \pm 0.2 \%$ $\mathrm{ADF}, 4.6 \pm 0.2 \% \mathrm{NDF}$, and $41.0 \pm 0.3 \%$ sugar.

${ }^{2}$ Corn silage had a DM content of $37.5 \pm 1.0 \%$ and chemical composition (DM basis) of $8.1 \pm 0.4 \% \mathrm{CP}, 22.5 \pm 2.6 \% \mathrm{ADF}$, and $35.7 \pm 4.4 \%$ NDF. Particle size distribution of corn silage (DM basis) was $8.3 \pm$ $5.9 \%$ long, $64.5 \pm 2.8 \%$ medium, $25.3 \pm 4.3 \%$ short, and $1.9 \pm 0.5 \%$ fine particles. Particle size was determined by Penn State Particle Separator, which has a 19-mm screen (long), 8-mm screen (medium), 1.18-mm screen (short), and a pan (fine).

${ }^{3}$ Alfalfa haylage had a DM content of $43.8 \pm 1.7 \%$ and chemical composition (DM basis) of $17.0 \pm 0.4 \% \mathrm{CP}, 32.4 \pm 0.9 \% \mathrm{ADF}$, and 45.4 $\pm 1.4 \%$ NDF. Particle size distribution of alfalfa haylage (DM basis) was $22.3 \pm 3.9 \%$ long, $51.5 \pm 2.9 \%$ medium, $21.4 \pm 1.0 \%$ short, and $4.8 \pm 1.4 \%$ fine particles.

${ }^{4}$ Supplied by Ritchie Feed \& Seed Inc. (Ottawa, ON, Canada), containing (on as-is basis) $25.3 \%$ corn gluten meal, $24.2 \%$ soybean meal, $24.1 \%$ Tri-Pro Gold (Tri-County Protein Corp., Winchester, ON, Canada), $9.9 \%$ canola meal, $5.3 \%$ ground limestone, $5.0 \%$ trace mineral/vitamin premix, $4.3 \%$ sodium bicarbonate, and $1.9 \%$ cobaltizediodized salt.

the dried TMR particle fractions, were sent to Cumberland Valley Analytical Services Inc. (Maugansville, $\mathrm{MD})$ for analysis of $\mathrm{DM}\left(135^{\circ} \mathrm{C}\right.$; $\mathrm{AOAC}, 2000$; method 930.15), ash $\left(535^{\circ} \mathrm{C}\right.$; AOAC, 2000; method 942.05), ADF (AOAC, 2000; method 973.18), NDF with heatstable $\alpha$-amylase and sodium sulfite (Van Soest et al., 1991), fat (AOAC, 2006; method 2003.05), starch (Hall, 2009), sugar (Dubois et al., 1956), and $\mathrm{CP}(\mathrm{N} \times 6.25)$ (AOAC 2000; method 990.03; Leco FP-528 Nitrogen Analyzer; Leco Corp., St. Joseph, MI).

\section{Milk Yield and Components}

Daily milk yield was recorded for each cow during the last $7 \mathrm{~d}$ of each treatment period, using Tru-Test milk meters (Westfalia Surge Canada Co., Mississauga, Ontario, Canada). Milk samples were collected from each cow from each milking during the last $3 \mathrm{~d}$ of the collection period. These samples were sent to the DHI laboratory (CanWest DHI, Guelph, Ontario, Canada) and analyzed for fat and protein content using a nearinfrared analyzer (Foss System 4000; Foss Electric A/S, Hillerød, Denmark). Milk fat and protein yield $(\mathrm{kg} / \mathrm{d})$ were calculated for the last $3 \mathrm{~d}$ of each treatment period based on the product of the milk yield and milk composition at each milking on those days. For those days, the yield of $4 \% \mathrm{FCM}(\mathrm{kg} / \mathrm{d})$ was calculated
$(\mathrm{NRC}, 2001)$ as $0.4 \times$ milk yield $(\mathrm{kg} / \mathrm{d})+15.0 \times$ fat yield $(\mathrm{kg} / \mathrm{d})$. Energy-corrected milk was calculated using the following equation: $\mathrm{ECM}=(0.327 \times \mathrm{kg}$ of milk $)$ $+(12.95 \times \mathrm{kg}$ of fat $)+(7.2 \times \mathrm{kg}$ of protein) (Tyrrell and Reid, 1965). Efficiency of milk production was determined by calculating the kilograms of milk, $4 \%$ FCM yield, or ECM yield per kilogram of DMI for the last 3 $\mathrm{d}$ of each treatment period.

\section{Calculations and Statistical Analysis}

Sorting activity for each fraction of the PSPS was calculated as the actual intake of each fraction expressed as a percentage of the predicted intake of that fraction (Leonardi and Armentano, 2003). The predicted intake of an individual fraction was calculated as the product of the DMI of the total diet multiplied by the DM percentage of that fraction in the fed TMR. Values equal to $100 \%$ indicate no sorting, $<100 \%$ indicate selective refusals (sorting against), and $>100 \%$ indicate preferential consumption (sorting for).

Data for the particle size DM and nutrient distribution, as well as the daily intakes, sorting activity, milk yield, milk composition, and production efficiency, were summarized for each cow by treatment period. To test whether sorting of the experimental diets occurred, sorting activity for each fraction of the PSPS was summarized by treatment and tested for a difference from 100 using $t$-tests. All data were then analyzed using the MIXED procedure of SAS (SAS Institute, 2009). The final model included the fixed effects of period, order of treatment exposure and treatment, the random effect of cow within order of treatment exposure, and the

Table 2. Chemical composition ${ }^{1}$ of the treatment diets (mean \pm SD)

\begin{tabular}{lrr}
\hline & \multicolumn{2}{c}{ Diet $^{2}$} \\
\cline { 2 - 3 } Item & \multicolumn{1}{c}{ Control } & \multicolumn{1}{c}{ LF } \\
\hline DM, \% & $51.9 \pm 0.61$ & $51.1 \pm 0.79$ \\
OM, \% of DM & $91.6 \pm 0.39$ & $91.2 \pm 0.21$ \\
CP, \% of DM & $16.5 \pm 0.95$ & $17.3 \pm 0.91$ \\
ADF, \% of DM & $19.1 \pm 0.86$ & $19.1 \pm 0.79$ \\
NDF, \% of DM & $29.1 \pm 0.57$ & $28.9 \pm 0.48$ \\
Fat, \% of DM & $2.6 \pm 0.17$ & $2.6 \pm 0.16$ \\
Starch, \% of DM & $27.5 \pm 1.22$ & $26.4 \pm 1.04$ \\
Sugar, \% of DM & $4.0 \pm 0.50$ & $5.4 \pm 0.34$ \\
NFC, \% of DM & $43.4 \pm 0.98$ & $42.3 \pm 1.04$ \\
NE, Mcal/kg of DM & $1.66 \pm 0.01$ & $1.65 \pm 0.01$ \\
TDN & $71.9 \pm 0.48$ & $71.6 \pm 0.54$ \\
\hline
\end{tabular}

${ }^{1}$ Values were obtained from chemical analysis of TMR samples; OM $=$ $100-\%$ ash $\mathrm{NFC}=100-(\% \mathrm{CP}+\% \mathrm{NDF}+\% \mathrm{fat}+\%$ ash $) ; \mathrm{NE}_{\mathrm{L}}$ and TDN were calculated based on NRC (2001) equations.

${ }^{2}$ Control $=$ control TMR; LF $=$ control TMR with $4.1 \%$ liquid feed (Dairy/Gold Rumen Enhancer; Liquid Feeds International Ltd., Innerkip, ON). 
residual error. To determine the effect feed sorting had on production parameters, sorting activity data were individually included as a continuous linear effect in the above-mentioned model; only those significant effects are further reported. All values reported are least squares means. Significance was declared at $P \leq 0.05$ and trends reported if $0.05<P \leq 0.10$.

\section{RESULTS}

Nutrient composition of the treatment diets were very similar (Table 2), with the exception of a $5 \%$ increase in CP percentage and a $35 \%$ increase in sugar percentage in the LF diet. Particle size distribution differed between diets (Table 3); a lesser amount of DM was retained on the bottom screen $(<8$ but $>1.18 \mathrm{~mm})$ and a greater amount of DM was retained in the top screen $(>19 \mathrm{~mm})$, middle screen $(<19$ but $>8 \mathrm{~mm})$, and pan $(<1.18 \mathrm{~mm})$ in the LF diet compared with the control diet. With the exception of a greater starch percentage of particles on the top screen in the LF diet, in general, the $\mathrm{ADF}, \mathrm{NDF}$, and starch concentrations of the different particle fractions were slightly lower for the LF diet. Sugar concentration was increased by $25 \%$ or greater in each of the particle fractions in the LF diet as compared with the control diet.

Cows sorted against long particles on both treatment diets (Table 4); the extent of this sorting was greater for the control diet. No sorting occurred for or against medium particles in the control diet; on the LF diet, cows sorted against medium particles. Cows sorted for short and fine particles, to a similar extent, on both treatment diets. Cows sorted against ADF and NDF on both treatment diets; the extent of the sorting against NDF was slightly greater on the LF diet. Starch was sorted for on both diets to a similar extent. On the control diet, cows did not sort for or against sugar; however, sugar was sorted for on the LF diet.

Differences in intakes between diets are reported in Table 5. Dry matter intake was $1.4 \mathrm{~kg} / \mathrm{d}$ higher when cows were fed the LF diet as compared with the control diet. Acid detergent fiber intake was also greater for the LF diet, whereas NDF intake tended to be higher for the LF diet. Starch intake did not differ between diets. Sugar intake was $45 \%$ greater for the LF diet as compared with the control diet. The amount of orts was similar between treatments.

While on the LF diet, cows tended to produce more milk than while on the control diet (Table 6); when accounting for fat and energy content, cows on the LF diet produced more 4\% FCM and ECM. Within both treatments, greater selection against the longest ration particles was associated with greater milk yield $[\mathrm{kg} / \mathrm{d}$ $=-0.11 \times$ sorting of long particles $(\%)+50.0 ; P=$
Table 3. Particle size distribution, ${ }^{1}$ ADF, NDF, starch, and sugar content of the particle fractions of the treatment diets (mean \pm SD)

\begin{tabular}{|c|c|c|}
\hline \multirow[b]{2}{*}{ Item } & \multicolumn{2}{|c|}{ Diet $^{2}$} \\
\hline & Control & $\mathrm{LF}$ \\
\hline \multicolumn{3}{|c|}{ \% DM retained on screen } \\
\hline Long & $4.6 \pm 1.67$ & $6.7 \pm 2.20$ \\
\hline Medium & $41.2 \pm 4.64$ & $43.2 \pm 5.31$ \\
\hline Short & $44.0 \pm 3.42$ & $38.5 \pm 3.51$ \\
\hline Fine & $10.2 \pm 2.59$ & $11.6 \pm 2.46$ \\
\hline \multicolumn{3}{|c|}{$\mathrm{ADF}, \%$ of screen DM } \\
\hline Long & $32.7 \pm 0.77$ & $29.2 \pm 1.26$ \\
\hline Medium & $25.0 \pm 1.27$ & $23.3 \pm 0.44$ \\
\hline Short & $14.2 \pm 0.13$ & $13.5 \pm 0.10$ \\
\hline Fine & $14.6 \pm 0.68$ & $13.1 \pm 0.87$ \\
\hline \multicolumn{3}{|c|}{ NDF, $\%$ of screen DM } \\
\hline Long & $48.5 \pm 1.28$ & $43.9 \pm 3.22$ \\
\hline Medium & $35.9 \pm 1.56$ & $34.0 \pm 1.22$ \\
\hline Short & $20.8 \pm 1.93$ & $20.4 \pm 1.23$ \\
\hline Fine & $19.1 \pm 0.30$ & $17.1 \pm 0.49$ \\
\hline \multicolumn{3}{|c|}{ Starch, \% of screen DM } \\
\hline Long & $12.4 \pm 0.34$ & $13.9 \pm 0.43$ \\
\hline Medium & $21.3 \pm 0.78$ & $20.7 \pm 0.70$ \\
\hline Short & $37.9 \pm 2.51$ & $34.3 \pm 1.90$ \\
\hline Fine & $33.3 \pm 2.50$ & $28.0 \pm 1.30$ \\
\hline \multicolumn{3}{|c|}{ Sugar, \% of screen DM } \\
\hline Long & $4.0 \pm 0.71$ & $5.8 \pm 1.13$ \\
\hline Medium & $4.9 \pm 0.42$ & $6.1 \pm 0.42$ \\
\hline Short & $3.9 \pm 0.21$ & $7.1 \pm 0.71$ \\
\hline Fine & $4.0 \pm 0.14$ & $5.0 \pm 0.35$ \\
\hline
\end{tabular}

${ }^{1}$ Particle size determined by Penn State Particle Separator, which has a 19-mm screen (long), 8-mm screen (medium), 1.18-mm screen (short) and a pan (fine).

${ }^{2}$ Control $=$ control $\mathrm{TMR} ; \mathrm{LF}=$ control $\mathrm{TMR}$ with $4.1 \%$ liquid feed (Dairy/Gold Rumen Enhancer; Liquid Feeds International Ltd., Innerkip, ON).

$0.02]$, greater $4 \% \mathrm{FCM}[\mathrm{kg} / \mathrm{d}=-0.11 \times$ sorting of long particles $(\%)+49.4 ; P=0.04]$, and greater ECM yield $[\mathrm{kg} / \mathrm{d}=-0.13 \times$ sorting of long particles $(\%)+54.0 ; P$ $=0.03]$. Milk fat and protein percentage did not differ between treatments (Table 6); however, as result of the difference in milk yield, cows fed the LF diet tended to produce more kilograms of milk fat and produced more kilograms of milk protein. No difference existed between treatments in the efficiency of milk production (Table 6). Within both treatments, greater sorting against the longest ration particles was associated with greater efficiency of milk production $[\mathrm{kg}$ of milk $/ \mathrm{kg}$ of $\mathrm{DMI}=-0.007 \times$ sorting of long particles $(\%)+2.09$; $P<0.001]$, greater efficiency of production of $4 \% \mathrm{FCM}$ $[\mathrm{kg}$ of $4 \% \mathrm{FCM} / \mathrm{kg}$ of DMI $=-0.008 \times$ sorting of long particles $(\%)+2.08 ; P=0.003]$, and greater efficiency of production of ECM $[\mathrm{kg}$ of ECM $/ \mathrm{kg}$ of DMI $=-0.008$ $\times$ sorting of long particles $(\%)+2.26 ; P=0.002]$.

\section{DISCUSSION}

This study was designed to evaluate the effects of adding a liquid molasses-based supplement, at a rate of 
Table 4. Effect of dietary treatments on the sorting $(\%)^{1}$ of long, medium, short, and fine particles ${ }^{2}$ and dietary nutrients

\begin{tabular}{lcccc}
\hline & \multicolumn{3}{c}{ Diet $^{3}$} & \\
\cline { 2 - 3 } Item & Control & LF & SED $^{4}$ & P-value \\
\hline Sorting of particle fractions, $\%$ & & & & \\
Long & 55.0 & 68.8 & 5.11 & 0.02 \\
Medium & $98.8 \dagger$ & 97.8 & 0.48 & 0.07 \\
Short & 104.7 & 104.7 & 0.48 & 0.93 \\
Fine & 107.9 & 109.3 & 1.31 & 0.16 \\
Sorting of dietary nutrients, \% & 98.1 & 97.8 & 0.17 & 0.11 \\
ADF & 97.9 & 97.3 & 0.20 & 0.01 \\
NDF & 101.4 & 101.2 & 0.21 & 0.32 \\
Starch & $99.5^{*}$ & 101.4 & 0.55 & 0.008 \\
Sugar & & & \\
\hline
\end{tabular}

${ }^{1}$ Sorting $\%=100 \times(\mathrm{n} \mathrm{DMI} / \mathrm{n}$ predicted DMI), where $\mathrm{n}=$ particle fraction (long, medium, short, or fine) or dietary nutrient (ADF, NDF, starch, or sugar). Sorting values equal to $100 \%$ indicate no sorting, $<100 \%$ indicate selective refusals (sorting against), and $>100 \%$ indicate preferential consumption (sorting for). Data are averaged over $4 \mathrm{~d}$ for 12 cows on each treatment.

${ }^{2}$ Particle size determined by Penn State Particle Separator, which has a 19-mm screen (long), 8-mm screen (medium), 1.18-mm screen (short), and a pan (fine).

${ }^{3}$ Control $=$ control TMR; LF $=$ control TMR with $4.1 \%$ liquid feed (Dairy/Gold Rumen Enhancer; Liquid Feeds International Ltd., Innerkip, ON).

${ }^{4}$ Standard error of the difference.

$\dagger P<0.10{ }^{*} P>0.05$; all other values are $P<0.05$ [these values express the difference in individual sorting values (within treatment) from $100 \%]$.

4.1\% DM, to a TMR on feed sorting and production of lactating dairy cows. As the LF was added directly to the control TMR, it displaced a proportion of each of the TMR components; thus, the compositions of the 2 diets tested were not intended to be exactly the same. It must be noted that the DM and chemical composition of the rations were actually very similar, with the primary exception of the expected increase in sugar concentration in the LF diet due to the high sugar content of the LF. The addition of the LF did change the DM particle distribution of the ration, resulting in a lesser proportion of short particles and a greater proportion of long, medium, and fine particles. One would predict that the adhesiveness of the molasses-based LF supplement would help bind the short ration particles to the longer ration particles, as seen by Oelker et al. (2009) for corn-silage based rations and Eastridge et al. (2011) for a TMR containing finely ground corn grain. It is worthwhile to note in the current study that more variability was observed in the proportions of the long and medium particles in the LF diet, suggesting that some inconsistency may have occurred in how well the LF was mixed through the TMR on a daily basis.

In support of our hypothesis, the addition of the LF to the TMR did result in less sorting against the longest ration particles. It can be surmised that the cows were actively consuming more of these longer particles because of the LF adhering to those particles. Cows were, in fact, choosing to eat the components high in sugar that were in the LF diet; on the LF diet, cows

Table 5. Intakes of DM and nutrients, and percentage of orts for treatment diets ${ }^{1}$

\begin{tabular}{|c|c|c|c|c|}
\hline \multirow[b]{2}{*}{ Item } & \multicolumn{2}{|c|}{$\operatorname{Diet}^{2}$} & \multirow[b]{2}{*}{$\mathrm{SED}^{3}$} & \multirow[b]{2}{*}{$P$-value } \\
\hline & Control & LF & & \\
\hline DMI, kg/d & 27.7 & 29.1 & 0.49 & 0.019 \\
\hline ADF intake, $\mathrm{kg} / \mathrm{d}$ & 5.2 & 5.4 & 0.09 & 0.03 \\
\hline NDF intake, kg/d & 7.9 & 8.2 & 0.13 & 0.06 \\
\hline Starch intake, $\mathrm{kg} / \mathrm{d}$ & 7.7 & 7.7 & 0.13 & 0.87 \\
\hline Sugar intake, $\mathrm{kg} / \mathrm{d}$ & 1.1 & 1.6 & 0.04 & $<0.001$ \\
\hline Orts, $\%$ & 11.6 & 11.0 & 0.76 & 0.42 \\
\hline
\end{tabular}


Table 6. Effect of dietary treatments on milk yield, milk composition, and milk component yield, and efficiency of production

\begin{tabular}{|c|c|c|c|c|}
\hline \multirow[b]{2}{*}{ Item } & \multicolumn{2}{|c|}{$\operatorname{Diet}^{1}$} & \multirow[b]{2}{*}{$\mathrm{SED}^{2}$} & \multirow[b]{2}{*}{$P$-value } \\
\hline & Control & $\mathrm{LF}$ & & \\
\hline \multicolumn{5}{|l|}{ Milk yield, $\mathrm{kg} / \mathrm{d}$} \\
\hline Milk $^{3}$ & 41.2 & 43.1 & 0.93 & 0.08 \\
\hline $4 \% \mathrm{FCM}^{4}$ & 39.7 & 42.8 & 1.22 & 0.05 \\
\hline $\mathrm{ECM}^{4}$ & 43.2 & 46.4 & 1.29 & 0.05 \\
\hline \multicolumn{5}{|c|}{ Milk composition, ${ }^{4} \%$} \\
\hline Fat & 3.81 & 3.92 & 0.07 & 0.42 \\
\hline Protein & 3.36 & 3.35 & 0.02 & 0.75 \\
\hline \multicolumn{5}{|c|}{ Milk component yield, ${ }^{4} \mathrm{~kg} / \mathrm{d}$} \\
\hline Fat & 1.55 & 1.68 & 0.06 & 0.10 \\
\hline Protein & 1.36 & 1.45 & 0.04 & 0.02 \\
\hline \multicolumn{5}{|c|}{ Efficiency of milk production, ${ }^{4} \mathrm{~kg} / \mathrm{kg}$} \\
\hline Milk/DMI & 1.51 & 1.56 & 0.05 & 0.30 \\
\hline $4 \% \mathrm{FCM} / \mathrm{DMI}$ & 1.46 & 1.53 & 0.06 & 0.24 \\
\hline ECM/DMI & 1.59 & 1.67 & 0.06 & 0.26 \\
\hline
\end{tabular}

${ }^{1}$ Control $=$ control TMR; LF $=$ control TMR with $4.1 \%$ liquid feed (Dairy/Gold Rumen Enhancer; Liquid Feeds International Ltd., Innerkip, ON).

${ }^{2}$ Standard error of the difference.

${ }^{3}$ Data are averaged over $7 \mathrm{~d}$ for 12 cows on each treatment.

${ }^{4}$ Data are averaged over $3 \mathrm{~d}$ for 12 cows on each treatment.

selected for sugar in the ration, whereas on the control ration, they did not select for or against it. This is the first study to clearly document a decrease in sorting with the addition of an LF to the diet. Oelker et al. (2009) reported, based on the change in particle size over the course of the day, a decrease in sorting with the addition of molasses-based LF to a corn silage-based diet. Unfortunately, those researchers did not show that data, nor did they accurately quantify the degree of sorting (based on actual and predicted amounts of particles consumed).

Molasses, or LF containing a high proportion of molasses, may be more effective than adding water at decreasing sorting for rations lower in DM content (Eastridge et al., 2011). In previous research, sorting against the longest ration particles was increased, rather than decreased, when water was added to a TMR with a DM content $<60 \%$ and containing no dry forage (Miller-Cushon and DeVries, 2009; Felton and DeVries, 2010). It was hypothesized by Miller-Cushon and DeVries (2009) that the addition of water to already high-moisture longer particles may have made those particles less palatable and, thus, increased sorting against those particles. In the present study, and that of Oelker et al. (2009) for a corn silage-based TMR, binding of the LF to the longer ration particles may have made those particles more palatable and, thus, contributed to decreased sorting against those particles. Alternatively, for drier rations, containing dry forage, addition of an LF may not be as suitable for decreasing sorting; Oelker et al. (2009) reported no effect of adding LF to an alfalfa hay-based TMR on changes in particle size over the course of the day. Similarly, Eastridge et al. (2011) reported that adding LF to dry TMR ( $>64 \%$ DM) did not affect sorting behavior. In such cases of using dry rations, the addition of water may be more suitable for decreasing sorting (Leonardi et al., 2005).

Cows consumed $1.4 \mathrm{~kg}$ more DM per day when on the LF diet, providing further support to our hypothesis that the addition of the LF would have made the ration more palatable. Addition of LF has yielded variable effects on DMI both within and across other studies. Broderick and Radloff (2004) demonstrated a $2.7 \mathrm{~kg} / \mathrm{d}$ increase in DMI when liquid molasses was supplemented at a rate of $3 \%$ of the diet DM (resulting in $4.9 \%$ dietary sugar). Those researchers, however, also reported that supplementing molasses at higher rates $(>6 \%$, resulting in $>7.4 \%$ dietary sugar) resulted in similar DMI to their nonsupplemented control ration. This may suggest that any increases in DMI associated with increased palatability of the LF may be masked if dietary sugar content gets too high, a situation that could lead to increased lactic acid accumulation, depressed fiber digestibility, and suppressed intake (Oelker et al., 2009). Firkins et al. (2008) reported that adding $3.25 \%$ of an LF (containing cane molasses and corn steep liquor), a product similar to that tested in the present study, resulted in greater DMI only for diets of reduced NFC concentration (37 vs. 40\%). Those researchers hypothesized that greater ruminal carbohydrate availability in diets higher in NFC would suppress DMI, and, thus, limit the potential ability of an LF to enhance palatability and improve DMI. Interestingly, the ration used in the present study had greater NFC content than the 
control ration used by Firkins et al. (2008), suggesting that other dietary factors had an influence on DMI (i.e., particle size distribution and ration fermentability), which may have differed between the diets tested. Based on the results of these previous studies, it is not surprising that no effects of molasses supplementation on DMI was seen in studies by Oelker et al. (2009) and Martel et al. (2011), who supplemented diets that were already high in dietary sugar $(>6.0 \%)$ and NFC (>43\%) content.

The $5.1 \%$ increase in DMI on the LF diet translated into a tendency to produce $1.9 \mathrm{~kg}$ more milk per day and 3.1 and $3.2 \mathrm{~kg} / \mathrm{d}$ increases in $4 \% \mathrm{FCM}$ and ECM, respectively. The greater difference in $4 \%$ FCM and ECM is largely explained by the numerical, however nonsignificant, increase in milk fat percentage on the LF diet. Greater milk yield, with no significant changes in milk component content, resulted in a tendency for increased yield of milk fat (by 8.4\%) and increased yield of milk protein (by 6.7\%) on the LF diet. A tendency for increased milk fat yield was also noted by Firkins et al. (2008) when adding an LF to a $37 \%$ NFC diet. Given that the percentage increase in milk component yield in the present study was greater than the percentage increase in DMI, higher component production likely came as result of both the LF promoting increased DMI and changes in rumen fermentation. No rumen fermentation measures were collected in this study; however, increases in milk fat yield with diets high in sugar have been consistently reported (Oba, 2011) and attributed to reduced trans-FA production in the rumen (Martel et al., 2011; Oba, 2011). Broderick and Radloff (2004) also reported, similar to DMI, that increasing liquid molasses supplementation had a quadratic effect on milk yield and milk component yield. Based on these quadratic effects, those researchers determined that $5.3 \%$ was the optimal dietary sugar concentration to maximize milk, protein, and SNF yields. In the present study, adding LF at a rate of $4.1 \%$ resulted in $5.4 \%$ dietary sugar; thus, the observed increases in milk yield and milk component yield would be expected based on the calculations of Broderick and Radloff (2004).

Given that both DMI and milk yield increased at a similar rate for the LF diet, it is not surprising that the efficiency of milk production was not affected by LF supplementation. This is similar to that reported in other studies of supplementing rations with liquid molasses or molasses-based LF (Firkins et al., 2008; Oelker et al., 2009; Martel et al., 2011). This suggests that the effect LF supplementation has on milk yield is more related to the associated increase in DMI, likely caused by increased palatability, rather than any associated effects on fermentation and digestibility.
Another notable result was the finding that, for both treatments, greater amounts of sorting against the longest ration particles was associated with greater milk yield and efficiency of production. DeVries et al. (2011) similarly reported that greater selection against the longest ration particles was associated with greater efficiency of milk production. Those researchers hypothesized that decreased consumption of longer ration particles would correspond with a decrease in forage intake, which would contribute to increased feed conversion efficiency (Yang and Beauchemin, 2006). It follows logically that those cows in the present study engaging in more sorting against long particles were more efficient and, at a given level of DMI, were thus able to produce more milk. Given that this effect was found to be across treatments, it must also be noted that the difference in milk yield observed between treatments was related more to the observed difference in DMI and not the difference in feed sorting. It seems, therefore, that despite having negative effects, including increased risk of acidosis (DeVries et al., 2008) and depressed milk fat yield (DeVries et al., 2011; Fish and DeVries, 2012), feed sorting may also have positive outcomes, including increased efficiency and yield. Further research is, thus, encouraged to fully understand these contradictory outcomes of feed sorting.

\section{CONCLUSIONS}

Addition of $4.1 \%$ of LF to a TMR did not noticeably change the nutrient composition of the ration with the exception of an expected increase in dietary sugar concentration (from 4.0 to $5.4 \%$ ). Liquid feed supplementation did affect particle size distribution of the ration, resulting in a lesser amount of short and a greater amount of fine particles. This shift in particle distribution, along with the increased palatability of the high-sugar containing LF, likely contributed to the decreased sorting observed against the longest ration particles as well as the increased DMI for the LF diet. As a result of the increased DMI, cows tended to produce more milk and did produce more $4 \% \mathrm{FCM}$ and ECM on the LF diet, resulting in cows tending to produce more kilograms of milk fat and producing more kilograms of milk protein. No difference existed between treatments in the efficiency of milk production. Overall, supplementation of a molasses-based LF to TMR can be used to decrease feed sorting, enhance DMI, and improve milk yield.

\section{ACKNOWLEDGMENTS}

We thank the staff and students at the University of Guelph, Kemptville Campus Dairy Education and 
Research Centre (Kemptville, ON, Canada). In particular, we thank Megan Bruce and Bianca Kitts of the University of Guelph, Kemptville Campus for their technical help. We also thank the Dairy Farmers of Canada (Ottawa, ON, Canada), the Canadian Dairy Commission (Ottawa, ON, Canada), and Agriculture and Agri-Food Canada (Ottawa, ON, Canada) for their financial support of this study. Additional project support was received from Liquid Feeds International Ltd. (Innerkip, ON, Canada); the Ontario Ministry of Agriculture, Food and Rural Affairs (OMAFRA; Guelph, ON, Canada); and from the Canadian Foundation for Innovation (CFI; Ottawa, ON, Canada) and the Ontario Research Fund (Toronto, ON, Canada).

\section{REFERENCES}

AOAC. 2000. Official Methods of Analysis. Vol. I. 17th ed. Association of Official Analytical Chemists International. Arlington, VA.

AOAC. 2006. Official Methods of Analysis. Vol. I. 18th ed. Association of Official Analytical Chemists International. Arlington, VA.

Bhandari, S. K., S. Li, K. H. Ominski, K. M. Wittenberg, and J. C. Plaizier. 2008. Effects of the chop lengths of alfalfa silage and oat silage on feed intake, milk production, feeding behavior, and rumen fermentation of dairy cows. J. Dairy Sci. 91:1942-1958.

Broderick, G. A., and W. J. Radloff. 2004. Effect of molasses supplementation on the production of lactating dairy cows fed diets based on alfalfa and corn silage. J. Dairy Sci. 87:2997-3009.

CCAC (Canadian Council on Animal Care). 2009. Guidelines on: The care and use of farm animals in research, teaching and testing. Canadian Council on Animal Care, Ottawa, ON, Canada.

DeVries, T. J., F. Dohme, and K. A. Beauchemin. 2008. Repeated ruminal acidosis challenges in lactating dairy cows at high and low risk for developing acidosis: Feed sorting. J. Dairy Sci. 91:39583967.

DeVries, T. J., L. Holtshausen, M. Oba, and K. A. Beauchemin. 2011. Effect of parity and stage of lactation on feed sorting behavior of lactating dairy cows. J. Dairy Sci. 94:4039-4045.

Dubois, M., K. A. Gilles, J. K. Hamilton, P. A. Rebers, and F. Smith. 1956. Colorimetric method for determination of sugars and related substances. Anal. Chem. 28:350-356.

Eastridge, M. L. 2006. Major advances in applied dairy cattle nutrition. J. Dairy Sci. 89:1311-1323.

Eastridge, M. L., A. H. Lefeld, A. M. Eilenfeld, P. N. Gott, W. S. Bowen, and J. L. Firkins. 2011. Corn grain and liquid feed as nonfiber carbohydrate sources in diets for lactating dairy cows. J. Dairy Sci. 94:3045-3053.

Felton, C. A., and T. J. DeVries. 2010. Effect of water addition to a total mixed ration on feed temperature, feed intake, sorting behavior, and milk production of dairy cows. J. Dairy Sci. 93:2651-2660.
Firkins, J. L., B. S. Oldick, J. Pantoja, C. Reveneau, L. E. Gilligan, and L. Carver. 2008. Efficacy of liquid feeds varying in concentration and composition of fat, nonprotein nitrogen, and nonfiber carbohydrates for lactating dairy cows. J. Dairy Sci. 91:1969-1984.

Fish, J. A., and T. J. DeVries. 2012. Short communication: Varying dietary dry matter concentration through water addition: Effect on nutrient intake and sorting of dairy cows in late lactation. J. Dairy Sci. 95:850-855.

Hall, M. B. 2009. Determination of starch, including maltooligosaccharides, in animal feeds: Comparison of methods and a method recommended for AOAC collaborative study. J. AOAC Int. 92:42-49.

Kononoff, P. J., A. J. Heinrichs, and D. R. Buckmaster. 2003. Modification of Penn State forage and total mixed ration particle separator and the effects of moisture content on its measurements. J. Dairy Sci. 86:1858-1863.

Leonardi, C., and L. E. Armentano. 2003. Effect of quantity, quality, and length of alfalfa hay on selective consumption by dairy cows. J. Dairy Sci. 86:557-564.

Leonardi, C., F. Giannico, and L. E. Armentano. 2005. Effect of water addition on selective consumption (sorting) of dry diets by dairy cattle. J. Dairy Sci. 88:1043-1049.

Martel, C. A., E. C. Titgemeyer, L. K. Mamedova, and B. J. Bradford. 2011. Dietary molasses increases ruminal $\mathrm{pH}$ and enhances ruminal biohydrogenation during milk fat depression. J. Dairy Sci. 94:3995-4004.

Miller-Cushon, E. K., and T. J. DeVries. 2009. Effect of dietary dry matter concentration on the sorting behavior of lactating dairy cows fed a total mixed ration. J. Dairy Sci. 92:3292-3298.

Morris, T. R. 1999. Experimental Design and Analysis in Animal Sciences. CABI Publishing, New York, NY.

NRC. 2001. Nutrient Requirements of Dairy Cattle. 7th rev. ed. Natl. Acad. Sci., Washington, DC.

Nombekela, S. W., M. R. Murphy, H. W. Gonyou, and J. I. Marden. 1994. Dietary preferences in early lactation cows as affected by primary tastes and some common feed flavors. J. Dairy Sci. 77:2393-2399.

Oba, M. 2011. Effects of feeding sugars on productivity of lactating dairy cows. Can. J. Anim. Sci. 91:37-46.

Oelker, E. R., C. Reveneau, and J. L. Firkins. 2009. Interaction of molasses and monensin in alfalfa hay- or corn silage-based diets on rumen fermentation, total tract digestibility, and milk production by Holstein cows. J. Dairy Sci. 92:270-285.

SAS Institute. 2009. SAS User's Guide: Statistics. Version 9.2. SAS Institute Inc., Cary, NC.

Shaver, R. D. 2002. Rumen acidosis in dairy cattle: Bunk management considerations. Adv. Dairy Technol. 14:241-249.

Tyrrell, H. F., and J. T. Reid. 1965. Prediction of the energy value of cow's milk. J. Dairy Sci. 48:1215-1223.

Van Soest, P. J., J. B. Robertson, and B. A. Lewis. 1991. Methods for dietary fiber, neutral detergent fiber and nonstarch polysaccharide in relation to animal nutrition. J. Dairy Sci. 74:3583-3597.

Yang, W. Z., and K. A. Beauchemin. 2006. Increasing the physically effective fiber content of dairy cow diets may lower efficiency of feed use. J. Dairy Sci. 89:2694-2704. 